depth without mentioning his beard; Johnston gives the reader few tools to understand the significance of this omission, though we are in his debt for drawing our attention to the fact that the omission is significant.

It is a testament to Johnston's erudition that Beard Fetish in Early Modern England stands up despite a severe weakness in half of its thesis. Directors of early modern drama should certainly avail themselves of the insights Johnston's hermeneutic strategy opens. Its thorough documentation of the extent to which masculinity and beardedness were fused in the late sixteenth and early seventeenth centuries is a vital contribution to an embodied historicism.

DIRK VON DER HORST, Graduate Theological Union

\title{
Kingsley-Smith, Jane.
}

\section{Cupid in Early Modern Literature and Culture.}

New York: Cambridge University Press, 2010. Pp. x, 264. ISBN 978-0-52176761-3 (hardcover) \$90.

Before his cherubic form graced countless postcards and prints, Cupid's history was a violent and chaotic one; the destructive desire that the boy-god unleashed wounded, subjugated, and perverted. Jane Kingsley-Smith's Cupid in Early Modern Literature and Culture lights the many faces of the young but allpowerful figure from the Middle Ages to the English Civil Wars. In her introduction, Kingsley-Smith establishes an adversarial relationship between Cupid and Protestantism, which she grounds in an iconoclastic mistrust of "Catholic" idolatry that Cupid represented. She argues that his association with lust and unruly desire were anathema to Protestants eager to emphasize chastity in marriage, and to clearly delineate legitimate and illicit love. Moving between art history and literature, Kingsley-Smith outlines a cultural history of the early modern Cupid as a lens onto larger English Protestant anxieties over sexual and religious mores.

The first chapter is titled "Cupid, Art and Idolatry." It opens with the anecdote of Captain John Harris's cabin painting of Cupid and Venus, which Kingsley-Smith uses to suggest an intriguing parallelism between the experience of idolatry and pornography in the Protestant imagination. After what is defined 
as a "medieval period of neglect," the chapter argues that Cupid reappeared in English Protestant literature as a pagan and therefore Catholic idol, channelling Protestant writers' simultaneous attraction to and suspicion of poetry and the arts. Kingsley-Smith argues that the Middle Ages saw no conflict between Cupid worship and Catholicism; the Reformation, however, emphasized the need to parse images and rituals, putting the newly re-classicized Cupid firmly on the wrong side of the new faith. Examining Tottel's Miscellany alongside Sidney's two Arcadias and Spenser's Faerie Queene, this chapter outlines the Pygmalian trap of the Cupid idol that, in spite of its evident artifice, draws forth a damning iconophilia. The chapter identifies in Spenser and Sidney's uses of Cupid a guilty critique of the iconoclasm that their own poetic techné may deserve.

Chapter 2, "Cupid, Death and Tragedy," explores his dark and violent ancestors in two parts. Kingsley-Smith first examines images of the plague angel, the evolving "De morte \& amore" engravings in Alciato's Emblematum liber, and various paintings of the love god with memento mori themes to unveil Cupid's blurring of distinctions between death and love, desire and destruction. Part 2 discusses Kyd's Soliman and Perseda and Middleton's Women Beware Women as well as a separate genre of "Cupidean tragedy" in which Cupid is the central agent of death, usually as a result of incest or otherwise forbidden sex. The chapter argues that Cupidean tragedy engages Calvinist suspicions of desire and abstinence in bloodthirsty scenes of divine judgment that probe larger political consequences of proscribed desire.

The book's more speculative third and fourth chapters target the gendered deployment of Cupid's dangerous allure. Chapter 3, "Cupid, Chastity and Rebellious Women," examines Cupid's particular aggression towards women in the late sixteenth century. Although the chapter argues that such misogynist skirmishes represented important loci of engagement and subversion by female political figures, its analyses of Mary Stuart and Elizabeth I tend more toward the ways in which their femininity was cast by others' portrayals in masques and pageants. In response to the rule of women, male writers shot Cupid's arrows to expose and punish subversive female desire, displacing Calvinist condemnations of masculine susceptibility to illicit desire onto women. The chapter identifies a simultaneous impulse to observe female desire, and to mark its need for control, as exemplified by Gismond of Salerne, Lyly's Sappho and Phao, Shakespeare's A Midsummer Night's Dream and Churchyard's Shew of Chastity performed before Elizabeth in 1578, in the midst of the D'Anjou 
marriage discussions. The chapter concludes with an examination of Mary Wroth's Pamphilia and Amphilanthus, identifying the poet's agency in manipulating various Cupids as foils for the feminine poetic Self in its masculine genre. Pamphilia's conflict with Cupid shapes a love that defies his iconic blindness, rejecting the sensuality of sight in favour of Neoplatonic principles, and a new ideal of constancy embodied in Pamphilia herself.

The fourth and most contentious chapter is entitled "Cupid and the Boy-the Pleasure and Pain of Boy-Love." It examines Cupid in Italian erotic painting and on the English stage, where he destabilizes gender categories and figures homoerotic and infantilist desire through meta-theatrical gesturing. Kingsley-Smith emphasizes the appealing vulnerability of the boy-model or boy-actor and his activation of underlying pedophilic or incestuous erotics. The chapter examines feminine desire for the Cupid-child exclusively through a maternal lens, and at times appears to identify early modern homosexuality with pedophilia. Nonetheless it affords intriguing and at times disturbing insights into Marlowe's Dido, Queen of Carthage, Jonson's Christmas His Masque, Kyd's Soliman and Perseda, and Sharpham's Cupid's Whirligig.

Chapter 5, “Cupid and Psyche': the Return of the Sacred?” traces Cupid's marriage from Apuleius to "Cupid and Psyche" plays at the Caroline court. It argues that successive English versions of the play deliberately veiled erotic appeal and violence, positing Charles and Henrietta Maria's centrality in motivating Cupid's domestication. An exploration of Henrietta Maria's appropriation of the 'Cupid and Psyche' motif as a political tool for asserting herself at court and for rehabilitating Catholicism in England follows. The discussion of Henrietta Maria's deployment of Cupid points to the absence in Chapter 3 of any examination of Elizabeth I's able manipulation of Petrarchan rhetoric in cementing her rule. A direct engagement with Petrarch, especially the Rime sparse, which does not figure in Kingsley-Smith's discussions, might yield important additional conclusions. There is also a series of categorizations and slippages that would benefit from nuance. In the introduction, the "Middle Ages" and "Renaissance" are sharply separated in spite of a long scholarly tradition that complicates such classifications. At times these periods are conflated with equally unproblematized "Catholicism" and "Protestantism" respectively, leading to an overly general distinction between "Protestant" and "Catholic" interactions with images. Nonetheless, this does not detract from the breadth 
of Kingsley-Smith's analyses, or from their numerous valuable insights into a figure that continues to generate enormous artistic and literary activity today.

Cynthia naZarian, Northwestern University

\section{Milton, John.}

Paradise Lost: The Biblically Annotated Edition. Ed. Matthew Stallard.

Macon, GA: Mercer University Press, 2011. Pp. xxxvi, 506. ISBN: 978-0-88146268-5 (hardcover) \$60.

The many excellent editions of Paradise Lost in print reveal the extraordinary range of Milton's sources in their footnotes. Matthew Stallard's new edition of Paradise Lost specializes in the central source that provides the subject of the poem: the Bible. Focusing exclusively on biblical allusions and references, Stallard calls attention to Milton's intense biblicism and to the qualities of the biblical culture in which he lived and wrote. Stallard's edition will help to introduce a new generation of readers to the history, scope, and nature of the Bible as a preeminent literary influence in the Renaissance.

Stallard introduces his project in distinct phases. He observes the prominence of the Bible in Milton's prose, noting his familiarity with the Geneva Bible and its marginal comments. He cites De Doctrina Christiana and the Doctrine and Discipline of Divorce to illustrate Milton's skill in marshalling biblical texts into arguments. He defines the "scripturally trained conscience" (xvii) as a basis for biblical expression, as each reader internalizes and contemplates scripture in the process of reading. As critics have recently observed, Milton promoted a politics of reading integral to his vision of the Reformation as an ongoing process. For Milton, Stallard argues, "the Bible is more than the marker of Protestant ideological discourse; it is the ultimate authoritative discourse" (xviii). Notwithstanding this biblical focus, the preface could briefly indicate how the scriptural conscience engages and organizes the resources of the wider literary culture, particularly classical literature, around the Bible, as we see in Areopagitica and Paradise Lost.

Stallard describes his editorial choices as conservative. He constructs a valuable taxonomy of biblical allusions. The Geneva Bible of 1560 serves as a 